Case report

\title{
ELBOW JOINT LUXATION IN A TEN MONTHS OLD ARABIAN COLT - A CASE REPORT
}

\author{
BRKLJAČA BOTTEGARO Nika ${ }^{1 *}$, GOTIĆ Jelena ${ }^{2}$, CAPAK Hrvoje ${ }^{3}$, \\ HUBER Doroteja ${ }^{4}$, KUČKO Agata ${ }^{5}$, VRBANAC Zoran ${ }^{3}$
}

${ }^{1}$ Surgery, Orthopaedics and Ophthalmology Clinic, Faculty of Veterinary Medicine, University of Zagreb, Zagreb, Croatia; ${ }^{2}$ Internal Disease Clinic, Faculty of Veterinary Medicine, University of Zagreb, Zagreb, Croatia; ${ }^{3}$ Department of Radiology, Ultrasound Diagnostic and Physical Therapy, Faculty of Veterinary Medicine, University of Zagreb, Zagreb, Croatia; ${ }^{4}$ Department of Veterinary Pathology, Faculty of Veterinary Medicine, University of Zagreb, Zagreb, Croatia; ${ }^{5}$ Student, Faculty of Veterinary Medicine, University of Zagreb, Zagreb, Croatia

(Received 15 October 2016, Accepted 15 January 2017)

Elbow joint luxation without concomitant fracture is uncommon in horses. This paper reports on a case of elbow joint luxation in a ten months old Arabian colt. The horse was presented with a history of an acute onset of non-weight bearing right front limb lameness with edema of the affected region lasting for six days. Radiographic imaging indicated luxation of the elbow joint; however, useful information about the severity of soft tissue involvement was obtained using ultrasonography since bilateral collateral ligaments were completely disrupted. The owner opted for euthanasia and necropsy confirmed the diagnosis. Although very rare, elbow joint luxation should be considered in cases of acute forelimb lameness in young horses.

Key words: collateral ligament, elbow joint, luxation, ultrasound.

\section{INTRODUCTION}

The elbow (humeroradial) joint is a ginglymus joint formed by the distal end of the humerus and its articulations with the proximal ends of the radius and ulna bones. The main movements of this joint are flexion and extension since anatomical arrangement impedes any medial to lateral movements [1]. Elbow joint luxation is not commonly reported in horses since the joint is protected from trauma by a close approximation with the body. Most described cases are associated with concomitant ulnar and/ or radial fracture, which occurs as a consequence of trauma causing severe limb abduction [2]. Clinical sings include acute onset of severe lameness with significant swelling of the affected region and inability to extend the carpus. Definitive diagnosis is made by radiographic imaging, although ultrasonography can also be very useful

\footnotetext{
*Corresponding author: e-mail: nikabottegaro@gmail.com
} 
in acquiring information regarding soft tissue structures. Possible management of elbow joint luxation in horses includes reduction, external immobilization and internal stabilization, although satisfactory results are difficult to achieve and postoperative complications are very common. Therefore, the prognosis is considered guarded to poor [2].

Elbow luxation without concomitant fractures has so far been described just a few times, solely in young horses up to eight months old [3-6]. This paper describes a case of an elbow luxation without concomitant fractures in a ten months old Arabian colt. For the first time we present both the ultrasonographic and pathomorphologic images of this condition in a young horse.

\section{CASE PRESENTATION}

The colt was admitted at the Faculty clinic with a history of acute onset of severe lameness lasting for six days. The animal was kept on pasture with other horses and till that event had been healthy. A traumatic incident was suspected, although not witnessed. Initial examination revealed non-weight bearing lameness of its right forelimb with the contralateral limb held adducted. The elbow and proximal radial region were severely swollen, the limb was held in semiflexion with a dropped elbow position and unable to extend the carpus (Fig. 1). There was no evidence of any wound over the affected region. Abduction of the affected limb elicited a painful response and caused crepitation sounds at the right elbow joint level. Neurological examination revealed no areas of cutaneous anaesthesia as triceps reflex and deep pain testing revealed no abnormalities, excluding radial paralysis. Radiographic examination was performed using two standard projections. X-ray imaging showed elbow joint luxation with lateral dislocation and slight contraction of both radius and ulna, evident in the craniocaudal projection (Fig. 2). More significant cranial and proximal dislocation of the radius and ulna were seen on lateromedial projection due to the antebrachial contraction (Fig. 3). There was no radiographic evidence of bone fracture. In order to perform ultrasonography the elbow region was clipped, followed by a 2 stage cleaning process using a surgical chlorhexidine gluconate scrub and ethanol solution to prepare the skin. A very high viscosity contact gel was applied on the skin. The examination was performed using a portable ultrasound Terason t-300 with a veterinary linear array transducer 5-12 MHz (Terason, 77 Terrace Hall Avenue, Burlington, MA 01803, United States). To examine the lateral collateral ligament the ultrasound transducer was positioned over the proximal origin on the lateral humeral epicondilar crest and moved distally towards the lateral radial tuberosity. Both sagittal and transverse images of the elbow region were performed. Ultrasonography revealed complete disruption of fiber patterns of both collateral ligaments, increased width between bones and fluid accumulation within the joint cavity. Medial part of the elbow region was partially evaluated due to a marked distress of the horse during the procedure what prevented us to obtain a presentable image. Selected ultrasonographic images of the lateral elbow 
region are presented in Figures 4.-6. Surgical therapy was proposed, but considering the poor prognosis for athletic soundness, the owner opted for euthanasia. Necropsy findings revealed extensive subcutaneous edema of the elbow region, as well as 10 $\mathrm{cm}$ around the joint, noted from the outside. On the surface cut, accumulation of extracellular, yellowish, transparent fluid was present as a gelatinous layer 3-5 mm thick between the superficial and deep fascial surfaces from the shoulder to the carpal joint. The integrity of the elbow joint was disrupted and dark red blood coagulum was found covering the distal and lateral humeral epiphysis as well as proximal and lateral radial and ulnar epiphyses. Olecranon was positioned outside of its physiologic location; it was found $3 \mathrm{~cm}$ dorsally and laterally from the usual location in the elbow joint. Collateral ligaments of both medial and lateral sides were ruptured and the synovial cavity was filled with dark red, gelatinous, coagulated blood (Fig. 7). The diagnosis of medial humeral luxation with subsequent hemarthros was confirmed.

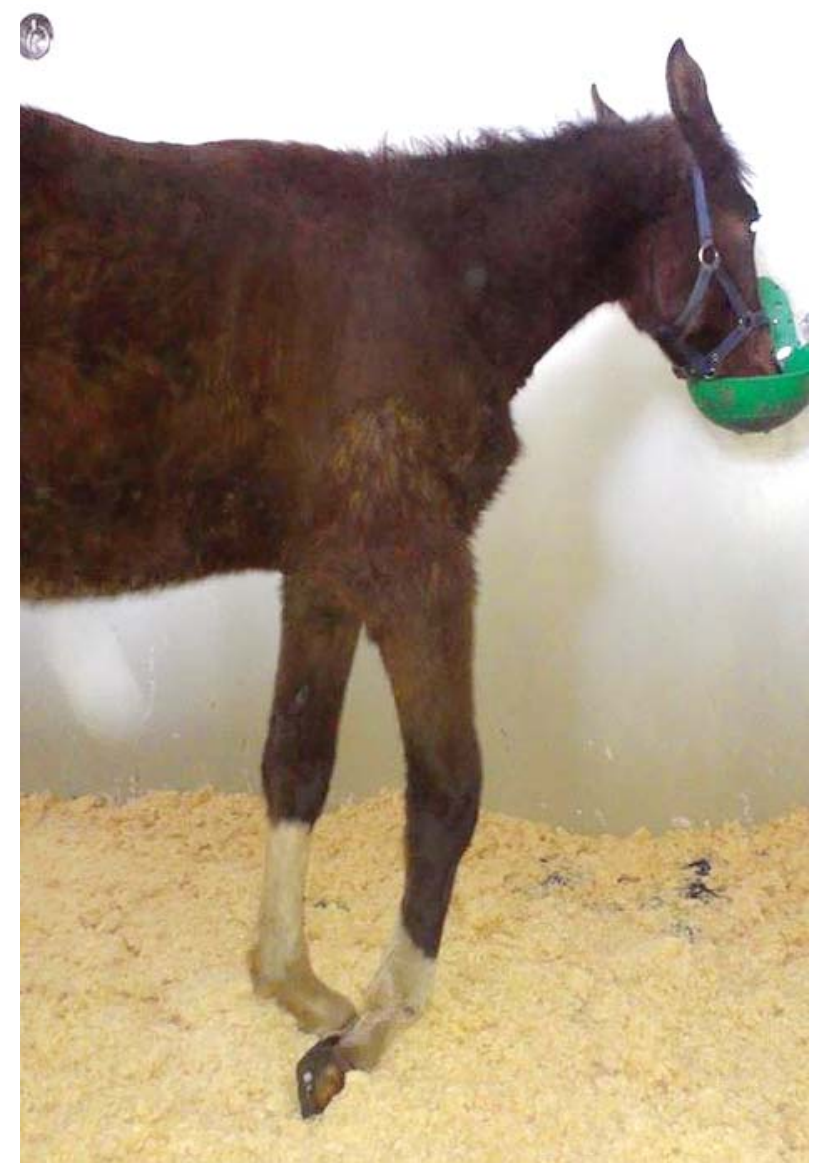

Figure 1. Non weight bearing lameness of the right forelimb with the limb held in semiflexion with a dropped elbow position. 


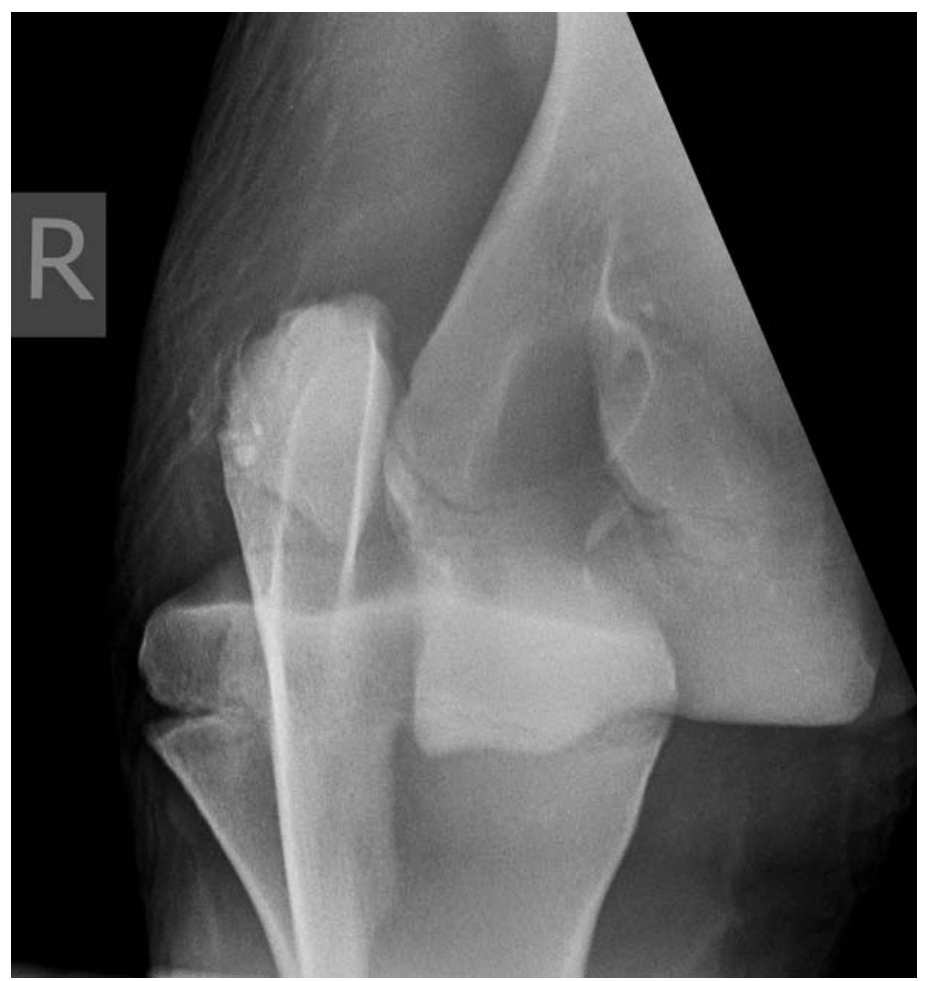

Figure 2. X-ray imaging in craniocaudal projection shows right elbow joint luxation

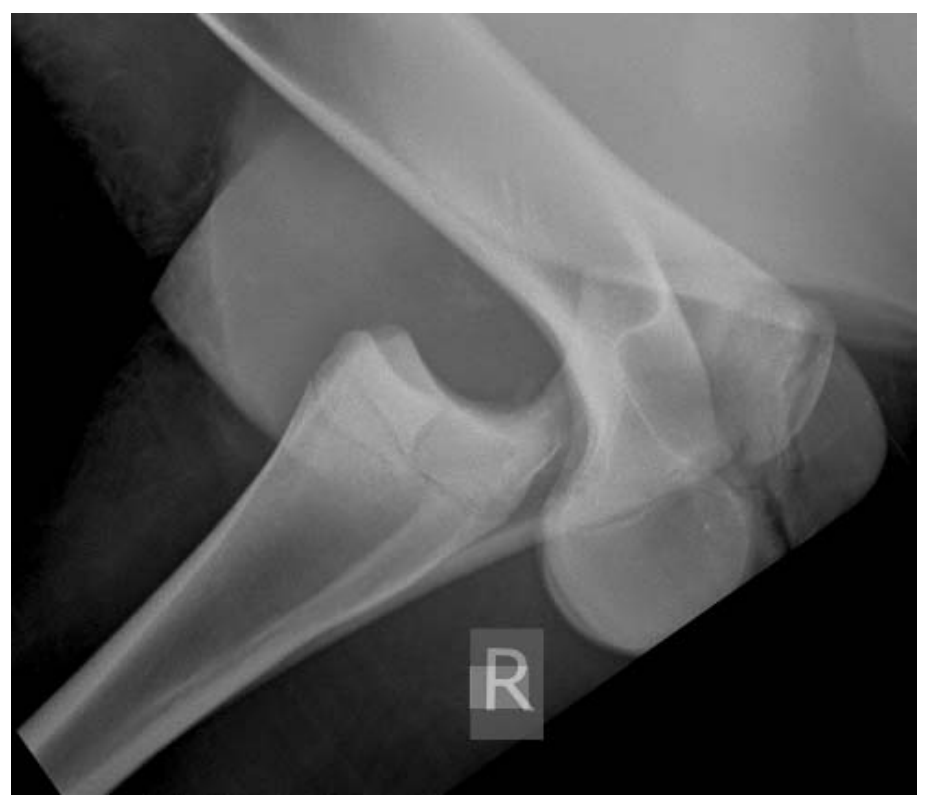

Figure 3. Lateromedial projection of luxated right elbow joint 

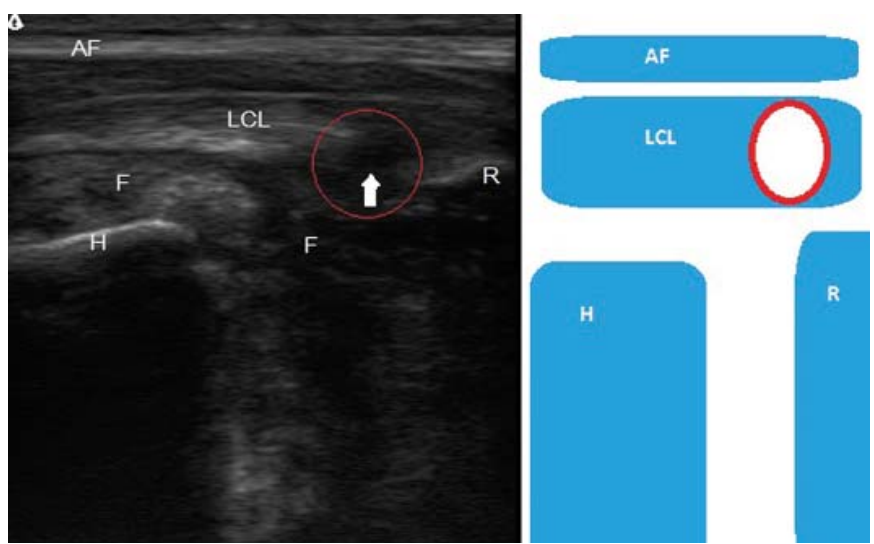

Figure 4. Sagittal image with corresponding diagram of the lateral cubital region. AFantebrachial fascia; LCL-lateral collateral ligament; U-ulna; H-humerus; F-fluid accumulation within the joint cavity; ARROW- disruption of fiber patterns of the lateral collateral ligament. Proximal is to the left.
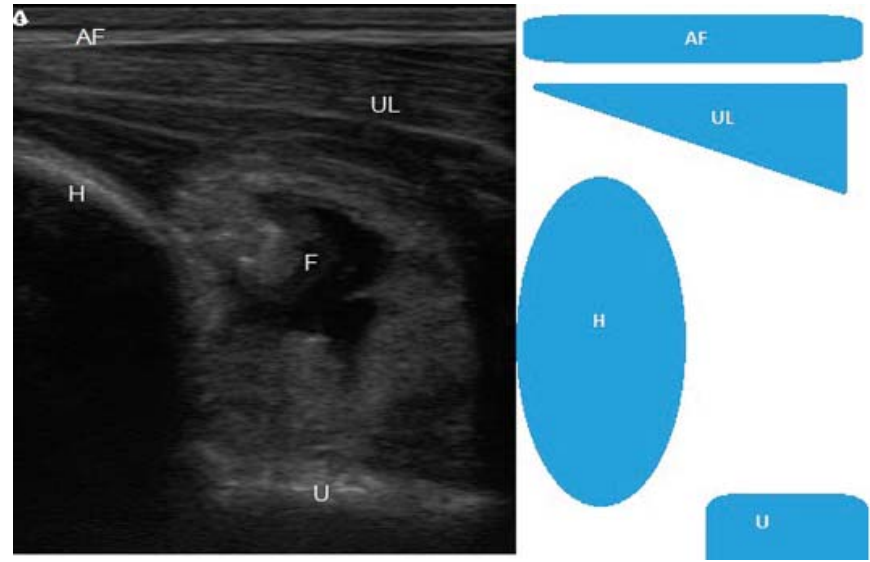

Figure 5. Sagittal image with the corresponding diagram of the lateral cubital region. AFantebrachial fascia; UL-ulnaris lateralis; ULT-tendon of the ulnaris lateralis muscle U-ulna; H-humerus; F-fluid accumulation within the join cavity. Proximal is to the left.

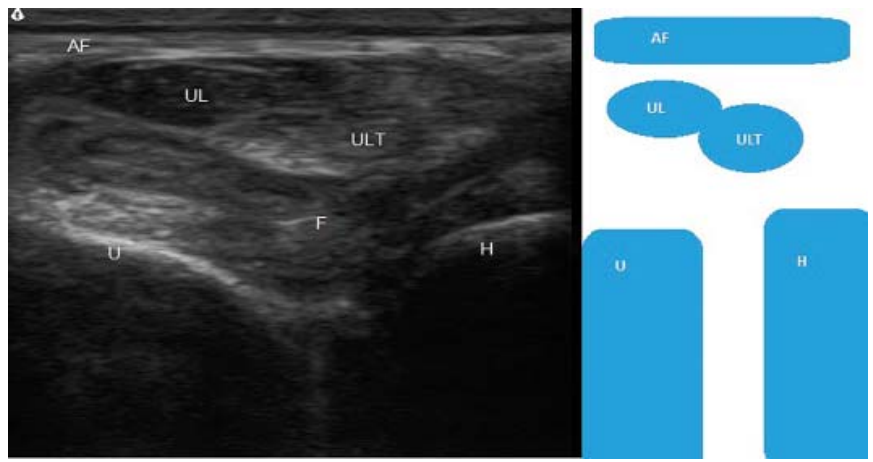

Figure 6. Transverse image with corresponding diagram of the lateral cubital region. AFantebrachial fascia; ULT-tendon of the ulnaris lateralis muscle; UL-ulnaris lateralis muscle; U-ulna; H-humerus; F-fluid accumulation. Lateral is to the left. 


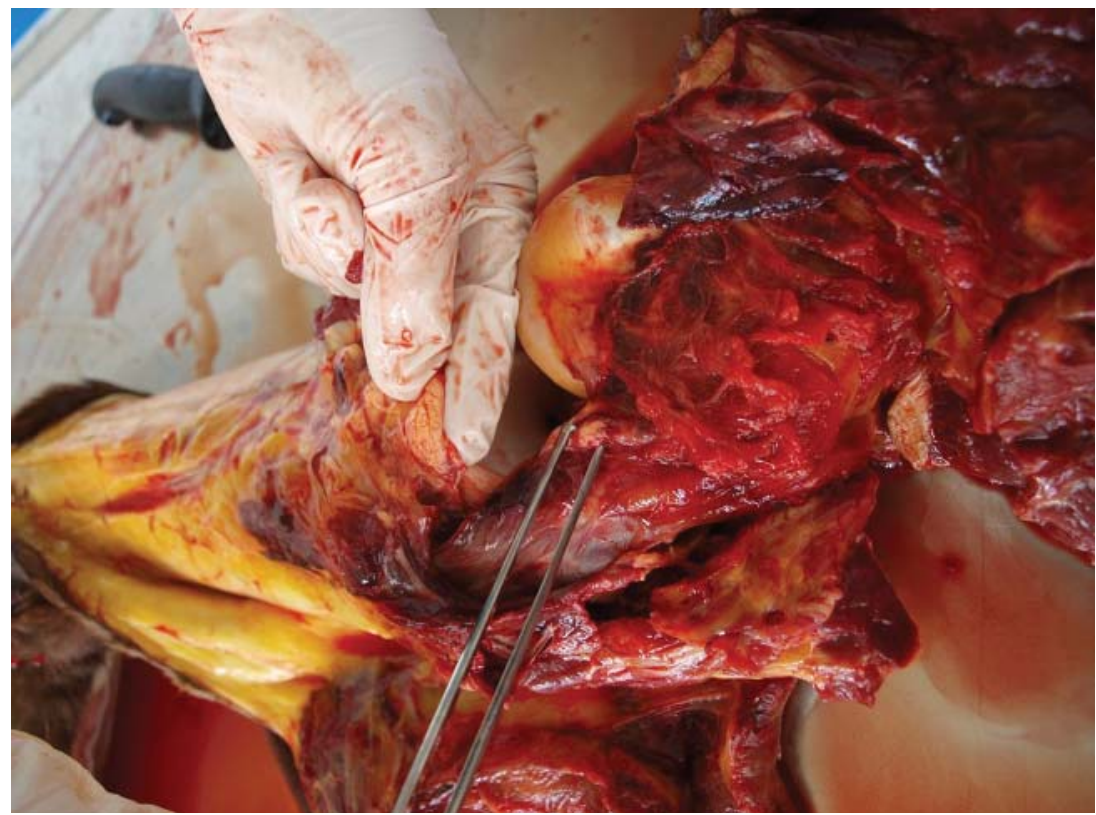

Figure 7. Necropsy finding, ruptured lateral collateral ligament.

Considering acute non weight bearing lameness, together with the dropped elbow appearance, a primary differential diagnosis of our case consisted of olecranon fracture, radial paralysis, fractures of proximal radius and distal humerus, since these pathologies are far more frequently encountered [7]. Elbow joint luxation causes ulnar and radial displacement dorsocaudally and laterally due to the larger size of the medial humeral epicondyle [5], coinciding with the findings in our case. In our report the exact cause of luxation remains unknown, although pasture with other horses indicates a likelihood of trauma. Senior at al. [8] described a case of an elbow joint subluxation in a pony during induction of general anaesthesia provoked by severe abduction of the limb. Humeroradial joint luxation without concomitant fractures has seldom been reported in horses and therefore scarce information regarding treatments and prognosis are available.

Different therapies of elbow joint luxation have been described in previous cases, although with limited success. The most successful surgery of an elbow joint luxation was described by $\mathrm{Hu}$ et al. [5] in a 10 weeks old foal. They opted for closed reduction and placing of only a lateral transarticular suture in a figure 8 tension band using monofilament nylon suture (Securos $36 \mathrm{~g}$ ). Providing only lateral stabilization of the elbow joint was efficient in the described case, although it is to be established if the same technique could be efficient in heavier horses. Hu et al. [5] did not perform an ultrasonography exam so no information about collateral ligaments condition was available and it remains doubtful if only lateral stabilization with prosthetic ligaments would be an adequate treatment option in cases of bilateral collateral ligament 
disruption. Taking into consideration that joint stability is mandatory for osteoarthritis prevention and thereby influences the possibility of future athletic use of the horse, elbow joint luxation still brings doubtful prognosis for sport horses. In our case there were more different points of concern regarding treatment options. At the time of admission there was already an obvious accumulation of blood clots between articular bones surfaces that could significantly complicate aneventual closed reduction of the dislocated joint. Closed reduction could be a treatment option in acutely referred cases, in particular in cases without complete collateral ligament disruption. However, in our case distinctive disruption of both collateral ligaments was clearly evident on ultrasonography examination aggravating the prognosis. Interestingly, ultrasonography was not performed in other elbow luxation reports [3-8] although already Chopin et al. [9] emphasize the use of this diagnostic tool in elbow join pathologies. Delayed case presentation could have also influenced the eventual postoperative infection since accumulated blood, blood clots, fibrin and devascularised tissue provide an excellent medium for microorganisms' growth, a complication already described by RubioMartinez et al. [6].

Elbow luxation is also infrequently reported in small animals [10,11]. Interestingly, contrary to horses, this pathology is far more frequent in older and larger animals since younger dogs are more likely to suffer fractures in the elbow joint [12]. In horses, elbow joint luxations have been described only in young animals [3-6], with our case representing the oldest horse. The only similar case described in adult horse was a case of an elbow subluxation in a pony during general anaesthesia induction reported by Senior et al [8].

Symptoms like acute forelimb non-weight bearing lameness should be sustained with comprehensive radiographic examination in order to make a diagnosis. Ultrasonography is an accessible beneficial tool that provides useful information about the condition of soft tissues in particular collateral ligaments. Elbow luxation is very painful for the horse and high quality of life cannot be provided. Although not commonly reported in horses, elbow luxation can be a cause of severe acute forelimb lameness especially in young animals.

\section{Authors' contributions}

BBN, GJ and VZ participated in case design. BBN and KA provided anamnestic and clinical data. HD performed necropsy and took photography. $\mathrm{CH}$ and $\mathrm{VZ}$ performed radiography and ultrasonography. GJ and KA carried out down literature research. All authors participated in manuscript drafting, read and approved the final manuscript.

\section{Declaration of conflicting interests}

The author(s) declared no potential conflicts of interest with respect to the research, authorship, and/or publication of this article. 


\title{
REFERENCES
}

1. Dyce KM: The forelimb of the horse. In: Textbook of Veterinary Anatomy, 2ndeds. Philadelphia, USA: WB Saunders; 1996, 578-582.

2. Stashak TS: Luxation and subluxation of the humeroradial (elbow) joint. In: Adams' Lameness in Horses 5 th eds. Philadelphia, USA: Lippincott Williams \& Wilkins; 2002, 888-890.

3. Crawley GR, Grant B: Repair of elbow joint luxation without concomitant fracture in a horse. Equine Pract 1986, 8:19-26.

4. Jones D: Closed reduction of a radiohumeral luxation in a mule. Equine Pract 1995, 17:3335 .

5. Hu AJ, Scheuch B, Cannon J: Repair of a complete luxation of the humeroradial joint in a foal with Securos suture. Equine Vet Educ 2007, 8:424-428.

6. Rubio-Martínez LM, Vázquez FJ, Romero A, Ormazábal JR: Elbow joint luxation in a 1-month-old foal. Aust Vet J 2008, 86:56-59.

7. Dyson, SJ: The elbow, brachium, and shoulder. In: Diagnosis and management of lameness in the borse. St. Louis, Missouri, USA: Elsevier Saunders; 2011, 456-474.

8. Senior M, Smith M, Clegg P: Subluxation of the left elbow joint in a pony at induction of general anaesthesia. Vet Rec 2002, 151:183-184.

9. Chopin JB, Wright JD, Melville L, Robinson WF: Lateral collateral ligament avulsion of the humeroradial joint in a horse. Vet Radiol Ultrasound 1997, 38:50-54.

10. O'Brien MG, Boudrieau RJ, Clark GN: Traumatic luxation of the cubital joint (elbow) in dogs: 44 cases (1978-1988). J Am Vet Med Assoc 1992, 11:1760-1765.

11. Mitchell KE: Traumatic elbow luxation in 14 dogs and 11 cats. Aust Vet J 2011, 6:213-216.

12. Schaeffer I, Wolvekamp P, Meij B, Theijse L, Hazewinkel: Traumatic luxation of the elbow joint in 31 dogs. Vet Comp Orthoped Traumatol 1999, 12:33-39.

\section{LUKSACIJA LAKATNOG ZGLOBA KOD DESET MESECI STAROG ŽDREBETA ARAPSKE RASE-PRIKAZ SLUČAJA}

\author{
BRKLJAČA BOTTEGARO Nika, GOTIĆ Jelena, CAPAK Hrvoje, \\ HUBER Doroteja, KUČKO Agata, VRBANAC Zoran
}

Luksacija lakatnog zgloba bez prisutnih preloma je retka pojava kod konja. U ovom radu je prikazan slučaj luksacije lakatnog zgloba kod deset meseci starog ždrebeta arapske rase. Ž drebe je dovedeno zbog akutne hromosti, praćene potpunim rasterećenjem desnog prednjeg ekstremiteta i pojavom edema u afektiranoj regiji u trajanju od šest dana. Radiološkim pregledom je ustanovljena luksacija lakatnog zgloba, međutim, značajne informacije o ozbiljnosti povrede mekih tkiva dobijene su primenom ultrasonografije kojom je ustanovljen potpuni prekid oba kolateralna ligamenata. Vlasnik se odlučio za eutanaziju, a obdukcijskim pregledom je potvrđena dijagnoza. Iako se retko javlja, luksaciju lakatnog zgloba treba razmotriti kao mogući uzrok hromosti prednjih ekstremiteta kod mladih konja. 